\title{
Effect of Halosulfuron Rate and Application Timing on Volunteer Azuki Bean Control in White Bean
}

\author{
Nader Soltani*, Lynette R. Brown, Peter H. Sikkema \\ University of Guelph Ridgetown Campus, Ridgetown, Canada \\ Email: ^soltanin@uoguelph.ca
}

How to cite this paper: Soltani, N., Brown, L.R. and Sikkema, P.H. (2020) Effect of Halosulfuron Rate and Application Timing on Volunteer Azuki Bean Control in White Bean. Agricultural Sciences, 11, 715-721. https://doi.org/10.4236/as.2020.118046

Received: July 4, 2020

Accepted: August 9, 2020

Published: August 12, 2020

Copyright $\odot 2020$ by author(s) and Scientific Research Publishing Inc. This work is licensed under the Creative Commons Attribution International License (CC BY 4.0).

http://creativecommons.org/licenses/by/4.0/

\section{(c) (i) Open Access}

\begin{abstract}
Three field experiments were carried out during 2017-2019 at the University of Guelph Huron Research Station near Exeter, Ontario, Canada to determine the effect of halosulfuron rate $\left(25,37.5\right.$ or $\left.50 \mathrm{~g} \cdot \mathrm{ai} \cdot \mathrm{ha}^{-1}\right)$ and application timing (POST 1, POST 2 and POST 3) on volunteer azuki bean control in white bean. At POST 1, halosulfuron at 25, 37.5 and $50 \mathrm{~g} \cdot \mathrm{ai} \cdot \mathrm{ha}^{-1}$ controlled volunteer azuki bean $46 \%-50 \%$ at 1 week after application (WAA), controlled decreased to $16 \%-25 \%$ at 8 WAA. At POST 2, volunteer azuki bean controlled decreased from $34 \%-39 \%$ at 1 WAA to $17 \%-27 \%$ at 8 WAA. A similar trend was observed at POST 3. Halosulfuron applied POST 1 at 25, 37.5 and $50 \mathrm{~g} \cdot \mathrm{ai} \cdot \mathrm{ha}^{-1}$ reduced biomass $49 \%, 64 \%$ and $69 \%$, respectively. Halosulfuron applied POST 2 did not reduce volunteer azuki bean biomass at $25 \mathrm{~g} \cdot \mathrm{ai} \cdot \mathrm{ha}^{-1}$, but decreased biomass $51 \%$ at $37.5 \mathrm{~g} \cdot \mathrm{ai} \cdot \mathrm{ha}^{-1}$ and $49 \%$ at $50 \mathrm{~g} \cdot \mathrm{ai} \cdot \mathrm{ha}^{-1}$. Similarly, halosulfuron applied POST 3 did not reduce volunteer azuki bean biomass at $25 \mathrm{~g} \cdot \mathrm{ai} \cdot \mathrm{ha}^{-1}$, but decreased biomass $40 \%$ at $37.5 \mathrm{~g} \cdot \mathrm{a} \cdot \mathrm{ha}^{-1}$ and $44 \%$ at 50 g.ai $\cdot \mathrm{ha}^{-1}$. There was as much as $19 \%, 22 \%$ and $25 \%$ dockage with halosulfuron applied POST 1, POST 2 and POST 3, respectively. Volunteer azuki bean interference reduced white bean yield $40 \%$. Reduced volunteer azuki bean interference with halosulfuron applied POST 1 at 37.5 or $50 \mathrm{~g} \cdot \mathrm{a} \cdot \mathrm{h} \mathrm{h}^{-1}$ resulted in an increase in white bean yield relative to the weedy control; however white yield was less than the weed-free control. This study concludes that halosulfuron at rates and application timings evaluated does not provide adequate control of volunteer azuki bean in white bean.
\end{abstract}

\section{Keywords}

Azuki Bean, Biomass, Aboveground Dry Weight, Dockage, Injury, Weed Control, White Bean, Phaseolus vulgaris, Vigna angularis 


\section{Introduction}

Azuki bean [Vigna angularis (Willd.) Ohwi \& Ohashi] is a protein-rich small red-brown coloured bean ( $5 \mathrm{~mm}$ long) that is widely grown in East Asia, mostly in China and Japan [1] [2] [3]. In recent years, azuki bean production has become popular among dry bean producers in Ontario as it can bring in up to three times the price of soybean on a tonnage basis [4]. Azuki bean production is so popular with dry bean growers in Ontario that their contracts are often filled months in advance [4]. Most of the azuki bean produced in Ontario is exported to Japan where it is used in confectionery products including pastry, soft drinks and chocolate bars [5]. One of the main concerns with azuki bean production is volunteer azuki bean in subsequent crops in the rotation. Azuki bean has a hardy seed that can survive and germinate up to 20 years after seed shed [6]. Studies have shown greater than $95 \%$ seed viability of azuki bean after 10 years [3].

White navy bean (Phaseolus vulgaris L.) is the largest market class of dry bean grown in Ontario. Volunteer azuki bean can be a serious challenge if white bean is grown after azuki bean as seeds from shattering losses of azuki bean during harvest operations can germinate and interfere with the white bean crop. Effective volunteer azuki bean control is essential for white bean growers as there is a significant downgrading and premium losses due to azuki bean seed contamination in white bean [7] [8]. The presence of volunteer azuki bean plants at white bean harvest can also decrease harvesting efficiency and lower seed quality. Azuki bean seeds are only marginally smaller than the white bean and are hard to separate from white bean. Yield losses of $31 \%$ have been reported when azuki bean was not controlled in white bean [9]. More research is needed to assess new herbicide programs that are safe for use in white bean and provide control of volunteer azuki bean.

Halosulfuron is a recently registered herbicide at the rate of 25 to $50 \mathrm{~g} \cdot \mathrm{ai} \cdot \mathrm{ha}^{-1}$ in Phaseolus vulgaris species including white bean in Ontario [10]. Halosulfuron is a Group 2 sulfonylurea herbicide that binds to the ALS enzyme which disrupts the synthesis of key amino acids [11]. Sulfonylurea herbicides are popular among growers as they have low mammalian toxicity, low use rates, can be tank-mixed with many other herbicides, and they provide effective control of a broad spectrum of weeds; although herbicide activity is active ingredient specific. Azuki bean is very sensitive to halosulfuron applied postemergence (POST); halosulfuron at 35 or $70 \mathrm{~g} \cdot \mathrm{ai} \cdot \mathrm{ha}^{-1}$ applied POST reduced azuki bean biomass reduction of $93 \%$ [12]. In addition to its activity on volunteer azuki bean, halosulfuron controls a wide range of common annual broadleaf weeds that occur in Ontario including Amaranthus species, common lambsquarters (Chenopodium album L.), common ragweed (Ambrosia artemesiifolia L.), velvetleaf (Abutilon theophrasti Medic.), wild mustard (Sinapis arvensis L.), ladysthumb [Persicaria maculosa (Gray)], common chickweed [Stellaria media (L.) Vill.], jimsonweed (Datura stramonium L.) and flower-of-an-hour (Hibiscus trionum L.). 
There is limited information on the efficacy of halosulfuron applied POST at various rates and application timings for the control of volunteer azuki bean in white bean under Ontario environmental conditions. Preliminary studies have shown that halosulfuron (35 g a.i. ha ${ }^{-1}$ ) applied preemergence (PRE) does not provide adequate control for volunteer azuki bean in white bean, but halosulfuron applied POST has the potential to provide some control of volunteer azuki bean in white bean [9]. Increasing the application rate of halosulfuron and adjusting the application timing may improve volunteer azuki bean in white bean.

The purpose of this study was to determine the effect of halosulfuron rate (25, 37.5 or $50 \mathrm{~g} \cdot \mathrm{ha}^{-1}$ ) and postemergence application timing [V1 (POST 1), V3 (POST 2) or V5 (POST 3) leaf stage] on the control of volunteer azuki bean in white bean.

\section{Materials and Methods}

Three field experiments were carried out over a three-year period (2017, 2018, and 2019) at the University of Guelph Huron Research Station near Exeter, Ontario, Canada. Seedbed was prepared with moldboard plowing in the autumn followed by two passes with a field cultivator (depth of $10 \mathrm{~cm}$ ) with rolling basket harrows in the spring. For uniform distribution of volunteer azuki bean seeds in the experimental plots, azuki bean seeds "Erimo" were distributed using a seed spreader at the rate of approximately $55 \mathrm{~kg} \cdot \mathrm{ha}^{-1}$ before cultivation in the spring.

The experiment design was a randomized complete block design with four replications. Treatments included a non-treated weedy control, weed-free control and halosulfuron applied POST 1 (V1 leaf stage), POST 2 (V3 leaf stage), and POST 3 (V5 leaf stage) at the rate of 25, 37.5 and $50 \mathrm{~g} \cdot \mathrm{ai} \cdot \mathrm{ha}^{-1}$. Plots were $3 \mathrm{~m}$ wide (4 rows spaced $75 \mathrm{~cm}$ apart) and $10 \mathrm{~m}$ long. White bean "T9905" was seeded at a rate of approximately 250,000 seeds $\mathrm{ha}^{-1}$ to a depth of approximately $4 \mathrm{~cm}$.

Halosulfuron treatments which included a nonionic surfactant $\left(\right.$ Agral $\left.90^{\circledR}\right)$ at $0.25 \% \mathrm{v} / \mathrm{v}$ were applied when the volunteer azuki bean was at V1 (POST 1), V3 (POST 2) and V5 (POST 3). Halosulfuron was applied with a backpack $\left(\mathrm{CO}_{2}\right.$-pressurized) sprayer adjusted to deliver $200 \mathrm{~L} \mathrm{ha}^{-1}$ at $207 \mathrm{kPa}$. The boom had four Ultra Lo-Drift (ULD 120-02) spray nozzles spaced $50 \mathrm{~cm}$ apart, producing a spray width of $2.0 \mathrm{~m}$. Percent volunteer azuki bean control was estimated visually on a scale of $0 \%$ to $100 \%(0=$ no control and $100=$ total control $)$ at 1, 2, 4 and 8 weeks after application (WAA). At 4 weeks after POST 3 application, density (plant counts) and biomass (shoot dry weight dried at $60^{\circ} \mathrm{C}$ ) of volunteer azuki bean were determined from two $0.25 \mathrm{~m}^{2}$ quadrats in each plot. Seed moisture content, dockage, and seed yield of white bean were measured at maturity. Dockage represented percent contamination in harvested white beans with volunteer azuki bean. White bean yield was adjusted to $18 \%$ seed moisture content.

Data was analyzed using the GLIMMIX procedure in SAS [13]. The treatments were replicated 4 times in a randomized complete block design. The fixed 
effect was herbicide treatment and random effects were year-location combinations (environment), replicate within environment and the environment by treatment interaction. The Shapiro-Wilk statistic, fit statistics, residual plots and the potential distributions were used to identify the best distribution and associated link function for each parameter. Least square means (LSMEANS) were calculated on the data scale by using the inverse link function, and pairwise comparisons were subjected to Tukey's adjustment before determining treatment differences at $\mathrm{P}<0.05$. The normal distribution and identity link was used for percent azuki bean control at 1, 2, 4 and 8 WAT, azuki bean density and dry weight, as well as white bean moisture and yield at harvest. Percent dockage was analyzed using the lognormal distribution and identity link. The weedy control was assigned a value of 0 for weed control, and the weed-free control was assigned a value of 0 for weed density, biomass and dockage, or 100 for weed control and was excluded from the analysis due to zero variance. Comparisons were still possible between the other treatments and the value zero using the LSMEANS output and differences were identified.

\section{Results and Discussion}

At $1 \mathrm{WAA}$, there was no effect of halosulfuron rate $\left(25,37.5\right.$ and $\left.50 \mathrm{~g} \cdot \mathrm{ai} \cdot \mathrm{ha}^{-1}\right)$ on volunteer azuki bean control in white bean. Halosulfuron at 25, 37.5 and 50 g.ai.ha ${ }^{-1}$ controlled volunteer azuki bean $46 \%, 49 \%$ and 50\% when applied POST $34 \%, 36 \%$ and $39 \%$ when applied POST 2 ; and $26 \%, 30 \%$ and $31 \%$ when applied POST 3, respectively (Table 1). Halosulfuron applied POST 1 at 25, 37.5 and 50 g.ai ha ${ }^{-1}$ provided greater control of volunteer azuki bean than when applied POST 3 at the same rates (Table 1).

At 2 WAA, there was no effect of halosulfuron rate $\left(25,37.5\right.$ and $\left.50 \mathrm{~g} \cdot \mathrm{ai} \cdot \mathrm{ha}^{-1}\right)$ on volunteer azuki bean control in white bean. Halosulfuron at 25, 37.5 and 50 g.ai.ha ${ }^{-1}$ controlled volunteer azuki bean $58 \%, 64 \%$ and $70 \%$ when applied POST 1; $45 \%, 52 \%$ and $55 \%$ when applied POST 2; and $45 \%, 51 \%$ and $56 \%$ when applied POST 3, respectively (Table 1). Halosulfuron applied POST 1 at $50 \mathrm{~g} \cdot \mathrm{ai} \cdot \mathrm{ha}^{-1}$ provided greater volunteer azuki bean control than the same rate at POST 2.

At $4 \mathrm{WAA}$, there was no effect of halosulfuron rate $\left(25,37.5\right.$ and $\left.50 \mathrm{~g} \cdot \mathrm{ai} \cdot \mathrm{ha}^{-1}\right)$ or application timing (POST 1, POST 2 or POST 3) on volunteer azuki bean control in white bean. Halosulfuron at $25,37.5$ and 50 g.ai $\cdot$ ha $^{-1}$ controlled volunteer azuki bean $31 \%, 39 \%$ and $47 \%$ when applied POST 1; 32\%, 36\% and $42 \%$ when applied POST 2; and 33\%, 43\% and 50\% when applied POST 3, respectively (Table 1).

Volunteer azuki bean control was lower at 8 WAA. There was generally no effect of halosulfuron rate $\left(25,37.5\right.$ and $\left.50 \mathrm{~g} \cdot \mathrm{ai} \cdot \mathrm{ha}^{-1}\right)$ or application timing (POST 1 , POST 2 or POST 3) on volunteer azuki bean control in white bean. Across the three rates, halosulfuron applied at POST 1, POST 2 and POST 3 controlled volunteer azuki bean only $16 \%-25 \%, 17 \%-27 \%$ and $18 \%-32 \%$, respectively. Results are similar to another study in which halosulfuron (30 g.ai ha $\left.{ }^{-1}\right)$ applied 
PRE or POST controlled volunteer azuki bean 12 and 60\%, respectively in white bean [9]. In contrast, another study has shown that halosulfuron applied POST at $35 \mathrm{~g} \cdot \mathrm{ai} \cdot \mathrm{ha}^{-1}$ can cause up to $81 \%$ injury in azuki bean [14]. Additionally, Stewart et al. [12] found up to $86 \%$ azuki bean injury with halosulfuron applied POST at $70 \mathrm{~g} \cdot \mathrm{ai} \cdot \mathrm{ha}^{-1}$. Soltani et al. [14] reported up to $73 \%$ injury to azuki bean with halosulfuron applied POST at 35 and $70 \mathrm{~g} \cdot \mathrm{ai}^{\mathrm{h}} \mathrm{ha}^{-1}$.

At 4 weeks after POST 3 application, there was no effect of halosulfuron rate $\left(25,37.5\right.$ and 50 g.ai.ha $\left.{ }^{-1}\right)$ or application timing (POST 1, POST 2 and POST 3) on volunteer azuki bean density in white bean. There was a trend for decreased volunteer azuki bean biomass as the rate of halosulfuron increased at various application timings. Halosulfuron applied POST 1 at 25, 37.5 and 50 g.ai.ha ${ }^{-1}$ reduced biomass $49 \%, 64 \%$ and $69 \%$, respectively (Table 1). Halosulfuron applied POST 2 did not reduce volunteer azuki bean biomass at $25 \mathrm{~g} \cdot \mathrm{ai} \cdot \mathrm{ha}^{-1}$, but decreased biomass $51 \%$ at $37.5 \mathrm{~g} \cdot \mathrm{ai} \cdot \mathrm{ha}^{-1}$ and $49 \%$ at $50 \mathrm{~g} \cdot \mathrm{ai} \cdot \mathrm{ha}^{-1}$. Similarly, halosulfuron applied POST 3 did not reduce volunteer azuki bean biomass at 25 $\mathrm{g} \cdot \mathrm{ai} \cdot \mathrm{ha}^{-1}$, but decreased biomass $40 \%$ at $37.5 \mathrm{~g} \cdot \mathrm{a} \cdot \mathrm{ha}^{-1}$ and $44 \%$ at $50 \mathrm{~g} \cdot \mathrm{ai} \cdot \mathrm{ha}^{-1}$ (Table 1). Results are similar to another study in which halosulfuron applied POST at $30 \mathrm{~g} \cdot \mathrm{ai} \cdot \mathrm{ha}^{-1}$ reduced volunteer azuki bean biomass $38 \%$ in white bean [9]. In contrast, Stewart et al. [12] reported up to $93 \%$ reduction in azuki bean biomass with halosulfuron applied POST at $70 \mathrm{~g} \cdot \mathrm{ai} \cdot \mathrm{ha}^{-1}$. Soltani et al. [14] found up to $68 \%$ reduction in azuki bean biomass with halosulfuron applied POST at 35 or $70 \mathrm{~g} \cdot \mathrm{ai} \cdot \mathrm{ha}^{-1}$.

Table 1. Percent control, density and biomass of azuki bean as well as percent dockage, seed moisture content at maturity and yield of white bean (2017-2019) treated with halosulfuron at three rates at three POST timings. Means followed by a different letter within a column are significantly different according to a Tukey-Kramer multiple range test at $\mathrm{P}<0.05$. $^{\mathrm{a}}$

\begin{tabular}{|c|c|c|c|c|c|c|c|c|c|c|c|}
\hline \multirow{2}{*}{ Treatment $^{\mathrm{b}}$} & \multirow{2}{*}{ Rate } & \multirow{2}{*}{$\begin{array}{c}\text { Trt. } \\
\text { Timing }\end{array}$} & \multicolumn{4}{|c|}{ Volunteer azuki bean control (\%) } & \multirow{2}{*}{$\begin{array}{c}\begin{array}{c}\text { Volunteer azuki } \\
\text { bean density }\end{array} \\
\left(\text { Plants } \cdot \mathrm{m}^{-2}\right)\end{array}$} & \multirow{2}{*}{$\begin{array}{c}\begin{array}{c}\text { Volunteer } \\
\text { azuki biomass }\end{array} \\
\left(\mathrm{g} \cdot \mathrm{m}^{-2}\right)\end{array}$} & \multirow{2}{*}{$\begin{array}{c}\begin{array}{c}\text { White bean } \\
\text { dockage }\end{array} \\
(\%)\end{array}$} & \multirow{2}{*}{$\begin{array}{c}\text { White bean } \\
\text { moisture }\end{array}$} & \multirow{2}{*}{$\begin{array}{c}\text { White } \\
\text { bean yield } \\
\left(\mathrm{T} \cdot \mathrm{ha}^{-1}\right)\end{array}$} \\
\hline & & & $1 \mathrm{WAA}$ & 2 WAA & 4 WAA & 8 WAA & & & & & \\
\hline Weed-Free & & & 100 & 100 & 100 & 100 & $0^{\mathrm{a}}$ & $0^{\mathrm{a}}$ & $0^{\mathrm{a}}$ & $17 \cdot 5$ & $3 \cdot 0^{\mathrm{a}}$ \\
\hline Weedy & & & $0^{\mathrm{d}}$ & $0^{\mathrm{d}}$ & $0^{\mathrm{b}}$ & $0^{c}$ & $32^{\mathrm{b}}$ & $1068^{\mathrm{e}}$ & $31^{c}$ & $17 \cdot 3$ & $1 \cdot 8^{c}$ \\
\hline Halosulfuron & 25 & POST 1 & $46^{\mathrm{ab}}$ & $58^{\mathrm{abc}}$ & $31^{\mathrm{a}}$ & $16^{\mathrm{b}}$ & $34^{\mathrm{b}}$ & $54 \cdot 2^{\mathrm{bcd}}$ & $19^{\mathrm{bc}}$ & $18 \cdot 4$ & $2 \cdot 1^{b c}$ \\
\hline Halosulfuron & 37.5 & POST 1 & $49^{\mathrm{a}}$ & $64^{\mathrm{ab}}$ & $39^{\mathrm{a}}$ & $18^{\mathrm{ab}}$ & $28^{\mathrm{b}}$ & $38.0^{\mathrm{bcd}}$ & $9^{\mathrm{b}}$ & $18 \cdot 3$ & $2 \cdot 4^{\mathrm{b}}$ \\
\hline Halosulfuron & 50 & POST 1 & $50^{\mathrm{a}}$ & $70^{\mathrm{a}}$ & $47^{\mathrm{a}}$ & $25^{\mathrm{ab}}$ & $28^{\mathrm{b}}$ & $33 \cdot 0^{\mathrm{b}}$ & $10^{\mathrm{b}}$ & $19 \cdot 0$ & $2 \cdot 4^{\mathrm{b}}$ \\
\hline Halosulfuron & 25 & POST 2 & $34^{\mathrm{abc}}$ & $45^{c}$ & $32^{\mathrm{a}}$ & $17^{\mathrm{ab}}$ & $41^{\mathrm{b}}$ & $72 \cdot 8^{\text {cde }}$ & $19^{b c}$ & 18.2 & $2 \cdot 1^{\mathrm{bc}}$ \\
\hline Halosulfuron & 37.5 & POST 2 & $36^{\mathrm{abc}}$ & $52^{\mathrm{bc}}$ & $36^{\mathrm{a}}$ & $22^{\mathrm{ab}}$ & $30^{\mathrm{b}}$ & $51 \cdot 9^{\mathrm{bcd}}$ & $22^{\mathrm{bc}}$ & $17 \cdot 9$ & $2 \cdot 1^{b c}$ \\
\hline Halosulfuron & 50 & POST 2 & $39^{\mathrm{abc}}$ & $55^{\mathrm{bc}}$ & $42^{\mathrm{a}}$ & $27^{\mathrm{ab}}$ & $31^{\mathrm{b}}$ & $54 \cdot 9^{\text {bcd }}$ & $18^{\mathrm{bc}}$ & $18 \cdot 5$ & $2 \cdot 2^{\mathrm{bc}}$ \\
\hline Halosulfuron & 25 & POST 3 & $26^{c}$ & $45^{c}$ & $33^{a}$ & $18^{\mathrm{ab}}$ & $33^{\mathrm{b}}$ & $78 \cdot 4^{\mathrm{de}}$ & $25^{\mathrm{bc}}$ & $18 \cdot 3$ & $2 \cdot 2^{b c}$ \\
\hline Halosulfuron & 37.5 & POST 3 & $30^{\mathrm{bc}}$ & $51^{b c}$ & $43^{\mathrm{a}}$ & $26^{\mathrm{ab}}$ & $37^{\mathrm{b}}$ & $64 \cdot 1^{\text {bcd }}$ & $17^{\mathrm{b}}$ & $19 \cdot 1$ & $2 \cdot 1^{\mathrm{bc}}$ \\
\hline Halosulfuron & 50 & POST 3 & $31^{b c}$ & $56^{\mathrm{abc}}$ & $50^{\mathrm{a}}$ & $32^{\mathrm{a}}$ & $27^{\mathrm{b}}$ & $59 \cdot 3^{\mathrm{bcd}}$ & $12^{\mathrm{b}}$ & $18 \cdot 3$ & $2 \cdot 2^{\mathrm{bc}}$ \\
\hline
\end{tabular}

${ }^{a}$ Abbreviations: WAA, weeks after application; POST, postemergence; Trt, treatment. ${ }^{\mathrm{b}} \mathrm{Hal}$ osulfuron treatments included $0.25 \% \mathrm{v} / \mathrm{v}$ Agral $90 .{ }^{~} \mathrm{POST} 1,2$ and 3 applications were made at V1, V3 and V5 azuki bean, respectively. 
There was a $31 \%$ dockage due to volunteer azuki bean in white bean (Table 1). The dockage was as much as $19 \%, 22 \%$ and $25 \%$ with the halosulfuron applied POST 1, POST 2 and POST 3, respectively (Table 1).

White bean seed moisture content at harvest time ranged from $17.3 \%-19.1 \%$ (Table 1). There was no effect of halosulfuron rate $\left(25,37.5\right.$ and $\left.50 \mathrm{~g} \cdot \mathrm{ai} \cdot \mathrm{ha}^{-1}\right)$ or application timing (POST 1, POST 2 and POST 3 ) on white bean seed moisture content (Table 1). This is similar to another study in which halosulfuron applied PRE or POST at 30 g.ai.ha ${ }^{-1}$ for volunteer azuki bean control did not have an effect on white bean maturity as measured by seed moisture content [9].

Volunteer azuki bean interference reduced white bean yield $40 \%$ (Table 1). Volunteer azuki bean interference with halosulfuron treatments reduced white bean yield 20\% - 30\%. Most of the halosulfuron treatments resulted in white bean yield that was similar to the weedy control. Halosulfuron applied POST 1 at 37.5 or $50 \mathrm{~g} \cdot \mathrm{ai} \cdot \mathrm{ha}^{-1}$ were the only herbicide treatments that resulted in white bean yield that was greater than the weedy control (Table 1). In other studies, reduce volunteer azuki bean interference with halosufuron applied POST at 30 g.ai.ha ${ }^{-1}$ resulted in an increase in white bean yield of $31 \%$ [9].

\section{Conclusion}

Generally, there was generally no effect of halosulfuron rate on volunteer azuki bean control in white bean. There was a trend for reduced volunteer azuki bean control as the application timing was delayed although results were not always statistically significant. Halosulfuron at rates evaluated controlled volunteer azuki bean up to $70 \%$ when applied POST 1; 55\% when applied POST 2; and 56\% when applied POST 3. Similarly, volunteer azuki bean biomass was reduced only $69 \%, 49 \%$ and $44 \%$ with halosulfuron applied POST 1, POST 2 and POST 3 at the highest registered rate $\left(50 \mathrm{~g} \cdot \mathrm{ai} \cdot \mathrm{ha}^{-1}\right)$, respectively. Volunteer azuki bean interference with halosulfuron treatments caused 19\% - 25\% dockage in white bean. Additionally, volunteer azuki bean interference with halosulfuron treatments reduced white bean yield $20 \%-30 \%$. Reduced volunteer azuki bean interference with halosulfuron applied POST 1 at 37.5 or $50 \mathrm{~g} \cdot \mathrm{ai} \cdot \mathrm{ha}^{-1}$ were the only herbicide treatments that resulted in white bean yield greater than the weedy control. Based on these results, halosulfuron applied POST 1, POST 2 or POST 3 at 25, 37.5 and $50 \mathrm{~g} \cdot \mathrm{ai} \cdot \mathrm{ha}^{-1}$ does not provide adequate volunteer azuki bean control in white bean. Further research is required to assess the safety and efficacy of halosulfuron plus new tank-mix partners for the control of volunteer azuki bean in white bean production.

\section{Acknowledgements}

This study was funded in part by Ontario Bean Growers (OBG).

\section{Conflicts of Interest}

The authors declare no conflicts of interest regarding the publication of this paper. 


\section{References}

[1] Breene, W.M. and Hardman, L.L. (1987) Anatomy of a Specialty Crop-The Adzuki Bean Experience. Retrieved from the University of Minnesota Digital Conservancy. http://hdl.handle.net/11299/202614

[2] Hang, A.N., McClary, D.C., Gilliland, G.C. and Lumpkin T.A. (1993) Plant Configuration and Population Effects on Yield of Azuki Bean in Washington State. In Janick, J. and Simon, J.E., Eds., New Crops, Wiley, New York, 588-590.

[3] Lumpkin, T.A. and McClary, D.C. (1994) Azuki Bean: Botany, Production and Uses. CAB International, Wallingford, UK.

[4] Lynch, C. (2019) Hensall Co-Op Looking for Adzuki Bean Growers in Eastern Ontario.

https://farmersforum.com/hensall-co-op-looking-for-adzuki-bean-growers-in-easte rn-ontario/.

[5] Uwaegbute, A.C. (1996) Adzuki beAn (Vigna angularis (Willd.) Ohwi et Ohashi). In: Nwokolo, E. and Smartt, J., Eds., Food and Feed from Legumes and Oilseeds, Springer, Boston, MA. https://doi.org/10.1007/978-1-4613-0433-3_22

[6] Hardman, L.L., Oplinger, E.S., Doll, J.D. and Combs, S.M. (1989) Alternative Field Crops Manual: Adzuki Bean. University of Wisconsin-Cooperative Extension, Madison.

[7] Duke, J. (2012) Handbook of Legumes of World Economic Importance. Springer Science and Business Media, New York.

[8] Kramer, C., Soltani, N., Robinson, D.E., Swanton, C.J. and Sikkema, P.H. (2012) Control of Volunteer Adzuki Bean in Soybean. Agricultural Sciences, 3, 501-509. https://doi.org/10.4236/as.2012.34059

[9] Soltani, N., Shropshire, C. and Sikkema, P.H. (2019) Control of Volunteer Adzuki Bean and Soybean in White Bean with Halosulfuron. Canadian Journal of Plant Science, 99, 375-378. https://doi.org/10.1139/cjps-2018-0261

[10] Ontario Ministry of Agriculture and Food and Rural Affairs (OMAFRA) (2010) Guide to Weed Control, Publication 75. Toronto, ON, 1-396.

[11] LaRossa, R.A. and Schloss J.V. (1984) The Sulfonylurea Herbicide Sulfometuron Methyl Is an Extremely Potent and Selective Inhibitor of Acetolactate Synthase in Salmonella typhimurium. Journal of Biological Chemistry, 259, 8753-8757.

[12] Stewart, C.L., Nurse, R.E., Gillard, C. and Sikkema, P.H. (2010) Tolerance of Adzuki Bean to Preplant-Incorporated, Pre-Emergence, and Post-Emergence Herbicides in Ontario, Canada. Weed Biology and Management, 10, 40-47. https://doi.org/10.1111/j.1445-6664.2010.00365.x

[13] SAS Institute Inc. (2013) SAS/STAT ${ }^{\circledR} 12.3$ User's Guide. SAS Institute Inc, Cary, NC. SAS Institute Inc. 2016. Base SAS ${ }^{\circledR}$ 9.4 Procedures Guide: Statistical Procedures, Fifth Edition. SAS Institute Inc, Cary, NC.

[14] Soltani, N., Shropshire, C. and Sikkema, P.H. (2012) Response of Dry Beans to Halosulfuron Applied Postemergence. Canadian Journal of Plant Science, 92, 723-728. https://doi.org/10.4141/cjps2011-220 